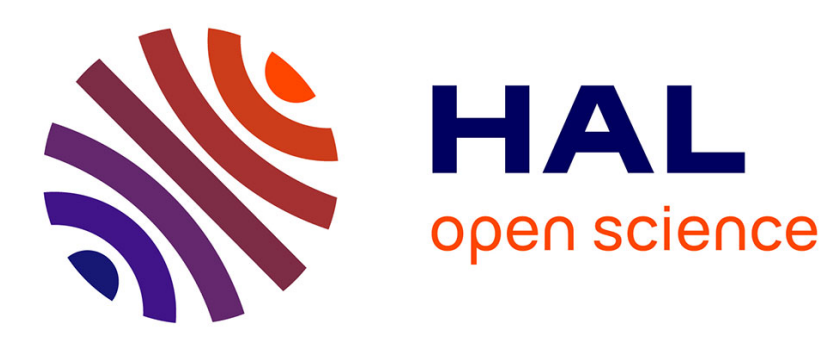

\title{
Supply Network Complexity: An Approach in a Global Aeronautic Industry in Brazil
}

Edison Sotolani Claudino, João Gilberto Mendes dos Reis

\section{To cite this version:}

Edison Sotolani Claudino, João Gilberto Mendes dos Reis. Supply Network Complexity: An Approach in a Global Aeronautic Industry in Brazil. IFIP International Conference on Advances in Production Management Systems (APMS), Sep 2014, Ajaccio, France. pp.489-496, 10.1007/978-3-662-447338_61. hal-01387310

\author{
HAL Id: hal-01387310 \\ https://hal.inria.fr/hal-01387310
}

Submitted on 25 Oct 2016

HAL is a multi-disciplinary open access archive for the deposit and dissemination of scientific research documents, whether they are published or not. The documents may come from teaching and research institutions in France or abroad, or from public or private research centers.
L'archive ouverte pluridisciplinaire HAL, est destinée au dépôt et à la diffusion de documents scientifiques de niveau recherche, publiés ou non, émanant des établissements d'enseignement et de recherche français ou étrangers, des laboratoires publics ou privés. 


\title{
Supply Network Complexity: an Approach in a Global Aeronautic Industry in Brazil
}

\author{
Edison Sotolani Claudino ${ }^{1}$ and João Gilberto Mendes dos Reis ${ }^{12}$ \\ ${ }^{1}$ Federal University of Grande Dourados, Postgraduate Studies Program in \\ Agribusiness \\ Dourados - Itaum Road km 12, 079804-970 Dourados, Brazil \\ 2 Paulista University, Postgraduate Studies Program in Production Engineering \\ Dr. Bacelar 1212, 04026-002 São Paulo, Brazil \\ edisonclaudino@ufgd.edu.br \\ betomendesreis@msn.com
}

\begin{abstract}
Operation management strategies have evolved from individual firms to clients and suppliers along the supply chain management. Concomitantly, the use of information technology, outsourcing and globalization has increased the complexity of these chains which have been recognized as supply networks. The aim of this study is presenting the supply network complexity, which are networks in which are involved products of high complexity encompassing global suppliers and clients as well. For this purpose, we performed a study about the theme and also presented a successful case related to the management of such network complexity in a Brazilian aeronautic industry.
\end{abstract}

Keywords. Globalization; Transnational companies; Aeronautic industry competition;

\section{Introduction}

In the last decades, world has evolved ever faster due to the constant improvement of the so-called Information and Communication Technology (ICT) which together with the outsourcing of the production activities and feedstock supply - and globalization as well - have significantly changed the scenery of the strategies in management operations [1], making them exceed the boundaries of the individual firm. In this sense, the concepts of Supply Chain Management (SCM) and Supply Networks [2] spring, using these new technologies for creating opportunities of business and efficiency income through the management of their two networks: upstream and downstream.

To follow these changes, Production and Operations Management (POM) has developed several systems and methodologies which allow a more strategic management, from which we highlight: Just-in-Time (JIT), Total Quality Management (TQM), Flexible Manufacturing Systems (FMS), Computer Integrated Manufacturing (CIM), Agile Manufacturing (AM), Lean Production (LP), Business Process Reengineering (BPR), Quick Response Manufacturing (QRM) and 
Clean Production (CP) [1]. However, SCM springs as a major branch encompassing all these systems and methodologies aiming to increase the profitability of companies and to respond the requests from final clients.

In this context, it is worth mentioning that supply chains have been named as supply networks, due to the innumerous relationships among them. Furthermore, supply networks have become even more complex because of (i) the high unit cost, (ii) the high intensity of engineering, (iii) the characteristics of the products, which are developed to meet specific demands from customers and (iv) for the high capacity to integrate knowledge and skills [3].

In this work we named such networks as Supply Networks Complexity and they are characterized by the complexity of the final product and the relationship between global customers and suppliers. The main aim of this study was to analyze the dynamics of these complex supply chains by studying the strategies used by a Brazilian aeronautic industry in order to manage its network complexity as well as the accomplishments of this enterprise related to the management of products.

In order to develop this work a literature review on supply chain management and supply networks was performed. Based on this study, the concept of Supply Network Complexity was established, so that it was possible to examine a case study in a Brazilian aeronautic industry that succeeded in reducing design time and costs in the production of aircrafts through the management of its suppliers and global customers.

\section{Supply Network Complexity}

The most significant change in the paradigm of the modern business management consists in the concept that individual organizations do not compete among themselves as unique entities, but as supply chains [4]. The study of these supply chains allowed us to follow the strategies of relationships among companies, suppliers and clients. The following Figure (1) illustrates this evolution, suggesting it was developed to reflect the real business practices in a growing evolution..

As its possible to observe, in Figure 2 theres a deepening of the management activities and material flows (i.e. supply chains seen as centered processes). Moreover, recent approaches focus on supply chain management as a system (i.e. management members and their mutually beneficial relations) with clear strategic intention [5].

Supply chains have been conceptualized as a simple linear system represented by an event which depends on a series of companies interacting through dyadic relation [6]. However, the linear concept of sequential dyadic relationships simplifies and distorts the realities of modern supply chains.

Modern supply chains can be considered complex and the adaptation to changes are required. Thus, there is a need to re-conceptualize the lines of a simple linear system to a complex adaptive system of supply networks [7], [8].

The complexity of a supply chain can not be consider a simple linear structure where a small change often results in a chain reaction. When supply chain 


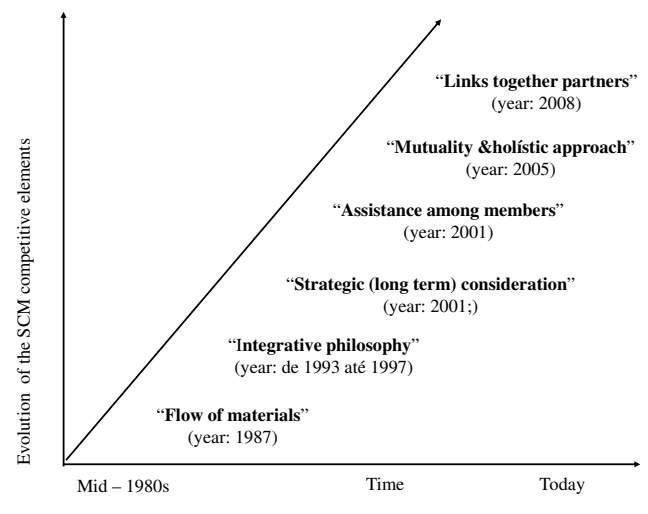

Fig. 1. Chronologic Evolution of the SCM competitive Elements. Source: Adapt [5]

complexity increases, monitoring and managing the interaction between different elements of the chain becomes more difficult [9].

Hearnshan and Wilson cited a complex approach of networks in which they propose that a supply chain is like a scale-free network (Figure 2) [10]. Thus, to reduce the vulnerability of the supply chain, the authors emphasize the need for managing constructions in redundancy, to undertake a strategy of multi-sourcing or intermediation among hubs companies, in other words, organizations that assume the responsibility of network management, either for the knowledge of the whole process, or for its economic power in the network relationships. More information about the model and BA scale-free network can be found in the work of [5].

Empirical models of the central-peripheral structure is observed in social systems of the real-world, including the flow of information in collaborative systems of researches in which pharmaceutical and biotech hubs companies collaborate closely sharing information for their mutual benefit. [10]. While all types of connections among hubs companies are possible to be found, the existence of a central-peripheral structure is further connected to the information flow since they have a closer triad structure [10].

In addition to the possible configurations and governance mechanisms for the supply networks, a company must currently not only manage its supply chain via active nodes, but also must have an adequate supervision on the supply network [9]. Thus, the identification of active and inactive members can be a strategic consideration for all the organization and part of its contingency plan 


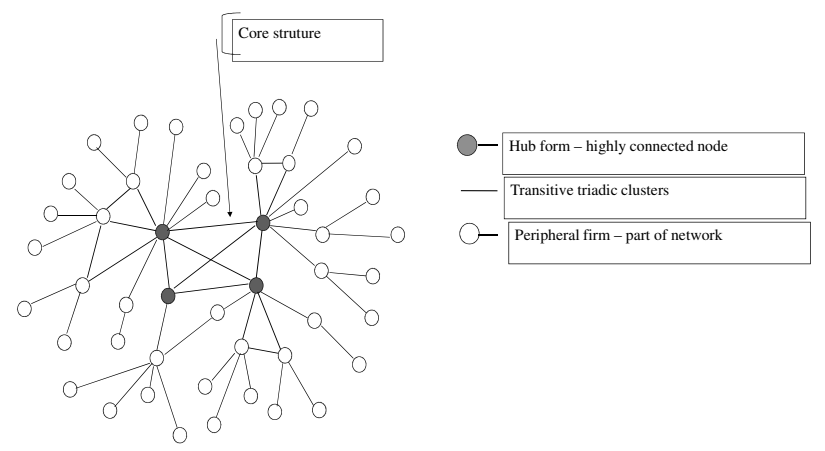

Fig. 2. Scale-free topology. Source: Adapt [10]

related to supplier. One way to illustrate the differences between supply chains and networks can be seen in Figure 3.

The supply chain is characterized by a perceivable linear structure (from raw material to final product), thus it is not totally complex, and its management is concerned to coordinate relevant flows as information, physical product and finance.

Supply networks, in turn, are an improved view of one or more supply chains, so the focus is on the net of relationships. As an example, an organization may have a connection with another company through a previous supplier who is not currently working. The integration in the supply network is more ad hoc, making it a complex, dynamic, nonlinear, based on trust and not-planned.

Moreover, supply network globalization of supply networks combined with the complexity of certain products makes the process of managing suppliers and customers a difficult task, which can only be accomplished through the use of ICTs.. Thus, such global networks of complex products that make a maximum use of these ICTs are named in this work as Supply Network Complexity.

Finally, the existing approaches towards complexity management in supply chains that can be found in literature can be structured into three essential process steps: identifying complexity drivers, measuring and evaluating the existing complexity, and developing strategies for managing complexity [11]. So, this study aim presents a case study that can show better these steps.

\section{Case study: aeronautic industry}

The analysis of the Supply Networks Complexity leads us to a case of successful management of these networks, which is connected to a large Brazilian aircraft 


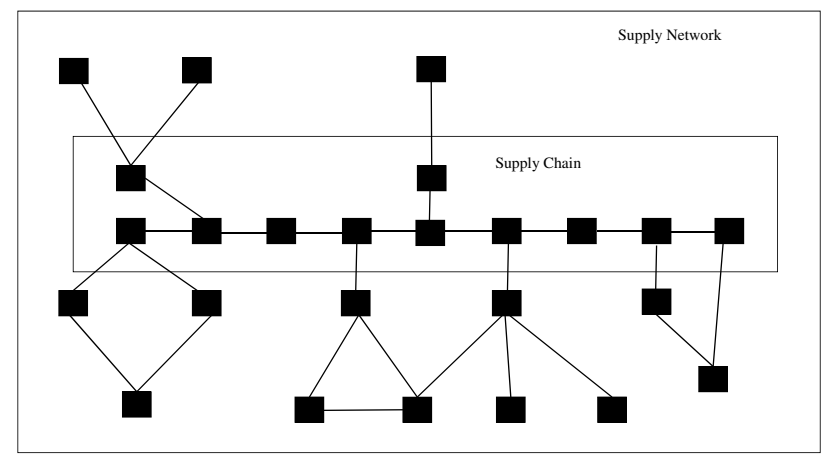

Fig. 3. Supply chain versus supply network. Source: Adapt [5]

manufacturer. The Company is today one of the largest aviation industries in the world, acting onto the steps of project, development, manufacture, sale and after-sale support of aircrafts for both commercial and executive aviation, besides offering integrated solutions for defense/security and systems.

With offices and factories in many parts of the world the company is a leader in the commercial jet market with up to 120 seats, and the fifth largest manufacturer of business jets worldwide and the largest company of defense and security solutions in Brazil [12]. Figure 4 demonstrates the international factories and offices of the company.

The evolution of the company related to product development engineering, held jointly with suppliers resulted in the management of supply network in a strategic way, which was crucial to its competitive success [2]. The industry was vertically integrated, but since the ' 90 s, has substantially altered its strategy to supply network to broaden its partnerships with key suppliers.

To illustrate this, in the ' 80 s, the company worked with more than 500 component suppliers without substantial sharing of engineering effort and development. The aircraft development was done internally, making the resource constraints take a long period - around 8 years - for the product to be placed on the market.

However, trying to strategically manage their supply network, the organization sought for technologically strong partners around the world who were committed to a more cooperative relationship among suppliers and company from product design sharing risks and costs of development. Several companies have already been selected to develop and supply structure equipments and inside parts of the aircraft, allowing suppliers reduction from 500 to 350 . This new model of supply management has generated a more technologically advanced product whose development period was reduced to five years. 


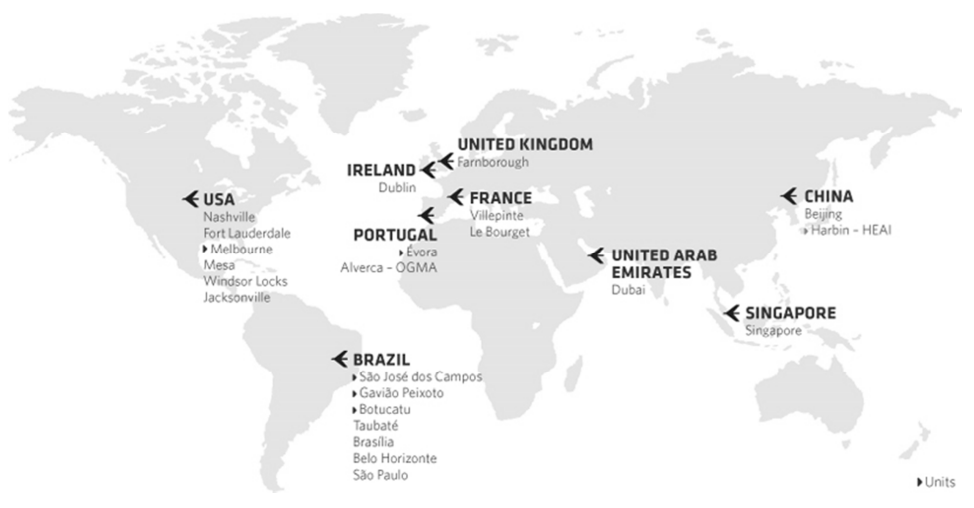

Fig. 4. The global operation of aeronautic industry, with assembly lines in Brazil, China, Portugal and the USA and service operations in other locations. Source: Adapt [12]

In the '90s, the supply network managers of this company continued to evolve in their strategic effort to increase the speed of product launches, technological upgrading and flexibility in responding the market [2]. The development of the aircraft project called ERJ 170, was innovative in several ways, either by engineering and institutional management of risk partnerships; or by the products integrated development tools (IDT) and the new management philosophy of codesign; as well for the built-edge technologies in the product, such as navigation systems fly-by-wire; and new production technologies, whose references are the techniques of lean production [3].

In project ERJ 170 one adopted the concept of group technology whose advantage is the commonality among the aircrafts and the co-design system for the development of the new aircraft project with risk partners. These two strategies are global trends, stimulated by technological nature of the product, market structure, high development cost and risk and rate of return on longterm investments, requiring from the risk partners a solid financial capacity for the investments supply. Table 1 highlights the risk partners of the project 170 .

The set of risk partners to integrate the 170 - program were selected from the analysis of 85 potential partners. From these, 58 were qualified, but only 12 were chosen. Aiming to manage the project, a directory exclusively dedicated was established to organize two central working groups: (i) first group, named Integrated Program Teams (IPT), charged to ensure functional vision and quality of the design of the aircraft subsystems; (ii) the second group, named Design 
Table 1. 170 Projects risk partners (country and component)

\begin{tabular}{cc}
\hline Country & Component \\
\hline Spain & Stabilizers and aft fuselage \\
Belgium & Slat / Central Fuselage II (Manufacturing) \\
USA & Interior \\
USA & Power generation system / APU, Tail Cut / air management system \\
USA & Flight control, fuel system and hydraulic system \\
USA & Avionics \\
Germany & Landing gear \\
Japan & Wings (board fixed attack, board fixed trail, stub, pylon, control surfaces \\
France & Central fuselage I/III / doors \\
USA & Engine / Nacelle \\
France & Providing the coating instrument panels and rib wings \\
USA & Production of transparencies / Windows \\
\hline
\end{tabular}

Source: Adapt [3]

Build Teams (DBT), was responsible for each physical segment of the aircraft [3]. As a result of this new management model of this complex supply network, the company reduced the development period of the product to less than four years [2].

Other initiatives undertaken by the company to strengthen its relationships with the suppliers were: (i) the creation of the SAC (Suppliers Advisory Council) to improve communication, share strategic and tactical decisions and improvement of the trust level in the relationship; and (ii) the annual world congress with its suppliers, SC (Supplier Conference). The company currently has a collaborative and effective relationship with suppliers, sharing risks and benefits from the development of the product, which makes the organization a success in managing the Supply Network Complexity.

\section{Conclusion and Outlook}

Globalization has allowed companies to have customers and suppliers around the world which makes the supply network management a complex task. Manufacturers of products that require a large number of parts and raw materials, skilled labor and high levels of security have increased this complexity and the management would not be possible without the use of modern Information and Communication Technologies. This study aimed to present that which was named Supply Network Complexity in order to represent networks that encompass this scenario.

The case study conducted in a Brazilian aeronautic industry has highlighted the results arising from the efficient management of these networks. Thus Brazil a country where companies are generally multinational and whose main products 
are commodities - managed to develop a company capable of producing high-tech aircraft, security and international competitiveness.

Clearly, further studies on these Supply Network Complexity need to be performed and analyzed other segments of industrial production so that we can effectively consider this term in Production and Operations Management.

\section{References}

1. Gunasekaran, A., Ngai, E.W.T.: The future of operations management: An outlook and analysis. International Journal of Production Economics 135(2), 687-701 (2012)

2. Corra, H.L.: Gesto de Redes de Suprimento: Integrando Cadeias de Suprimento no Mundo Globalizado. 1 edn. (2010)

3. Oliveira, L.G.d.: The development of complex systems projects in the aeronautical industry: the case of integrated management applied to the program embraer 170 . Cadernos EBAPE.BR 7(1), 19-33 (Mar 2009)

4. Lambert, D., Cooper, M.: Issues in supply chain management - don't automate, obliterate. Industrial Marketing Management 29(1), 65-83 (2000)

5. Braziotis, C., Bourlakis, M., Rogers, H., Tannock, J.: Supply chains and supply networks: distinctions and overlaps. Supply Chain Management: An International Journal 18(6), 644-652 (Sep 2013)

6. Cox, A., Sanderson, J., Watson, G.: Supply chains and power regimes: Toward an analytic framework for managing extended networks of buyer and supplier relationships. Journal of Supply Chain Management 37(1), 28-35 (Mar 2001)

7. Pathak, S.D., Day, J.M., Nair, A., Sawaya, W.J., Kristal, M.M.: Complexity and adaptivity in supply networks: Building supply network theory using a complex adaptive systems perspective*. Decision Sciences 38(4), 547-580 (Nov 2007)

8. Li, G., Yang, H., Sun, L., Ji, P., Feng, L.: The evolutionary complexity of complex adaptive supply networks: A simulation and case study. International Journal of Production Economics 124(2), 310-330 (2010)

9. Cheng, C.Y., Chen, T.L., Chen, Y.Y.: An analysis of the structural complexity of supply chain networks. Applied Mathematical Modelling 38(910), 2328-2344 (May 2014)

10. Hearnshaw, E.J.S., Wilson, M.M.J.: A complex network approach to supply chain network theory. International Journal of Operations \& Production Management 33(4), 442-469 (Mar 2013)

11. Aelker, J., Bauernhansl, T., Ehm, H.: Managing complexity in supply chains: A discussion of current approaches on the example of the semiconductor industry. Procedia CIRP 7(0), 79-84 (2013)

12. EMBRAER: Global presence (2014), http://www.embraer.com.br/en-us/ conhecaembraer/presencaglobal/pages/home.aspx 